\title{
C-reactive protein in childhood dermatomyositis
}

\author{
R. H. HAAS, R. F. DYCK ${ }^{*}$ V. DUBOWITZ, AND M. B. PEPYS \\ From the Department of Paediatrics and Neonatal Medicine (Institute of Child Health), and the \\ *Immunological Medicine Unit, Department of Medicine, Royal Postgraduate Medical School, Hammersmith \\ Hospital, London W12 OHS
}

\begin{abstract}
SUMMARY Serum levels of C-reactive protein (CRP) were determined in 9 patients with childhood dermatomyositis. Four children were seen during clinical relapse and all had serum CRP levels less than $1 \mathrm{mg} / \mathrm{l}$. In addition direct immunofluorescent staining of muscle biopsies from 4 patients showed no evidence of CRP deposition in muscle tissue. Such patients appear to be able to produce CRP in response to acute infections, and it is suggested therefore that the pathological process in childhood dermatomyositis may not induce a significant CRP response.
\end{abstract}

C-reactive protein is the classical acute-phase reactant, and although produced nonspecifically in response to tissue injury there is evidence that the levels of CRP which are attained may vary significantly between different diseases. ${ }^{1-3}$. Dermatomyositis is characterise by extensive inflammation and muscle necrosis, but in the only case in which it has previously been reported serum CRP was not detected, albeit by an insensitive assay. ${ }^{4}$

We report here that among 9 cases of childhood dermatomyositis, 4 (cases 1, 2, 3, 4) seen during an active phase of their disease had serum CRP levels of less than $1 \mathrm{mg} / \mathrm{l}$ (Table 1). Three children (cases 6,7, 8 ) had 'burnt-out' disease. One (case 7) was well apart from widespread calcinosis and no serum CRP was detected. When subsequently reassessed with healing local skin ulcers, the CRP level was $4 \mathrm{mg} / \mathrm{l}$. The second child (also with calcinosis) (case 6) was well and had no detectable CRP, but the third patient (case 8 ) with a paronychia on one toe had an elevated CRP of $20 \mathrm{mg} / \mathrm{l}$. Patient 9 had minimally elevated levels of CRP on 2 occasions, while patient 5 , whose disease was well controlled by steroids, was clinically well with a CRP of $57 \mathrm{mg} / \mathrm{l}$ when seen for review as a day patient. A subclinical infection could not be ruled out, and a second CRP determination done 4 months later was $10 \mathrm{mg} / \mathrm{l}$.

Accepted for publication 4 September 1981 .

Correspondence to Dr M. B. Pepys, Immunological Medicine Unit, Department of Medicine, Royal Postgraduate Medical School, Du Cane Road, London W12 0HS.
CRP was not detected by direct immunofluorescence in the muscle biopsies of the 4 children (cases 3 . $4,6,7)$ tested or in normal muscle tissue. Complement profiles were within normal limits in all patients in whom they were measured.

The results demonstrate that in children active involvement of muscle tissue in the inflammation and necrosis of dermatomyositis is not associated with appreciable elevation of the serum CRP concentration. This is not apparently due to deposition of CRP in the damaged muscle, nor to inability to produce CRP, since at least one of the patients had a significant response to an intercurrent infection.

Our observations extend the range of inflammatory disorders in which even extensive tissue damage is associated with only a modest elevation of serum CRP. This is the case in both systemic lupus erythematosus ${ }^{4{ }^{810-13}}$ and ulcerative colitis ${ }^{14}$ and contrasts sharply with the high CRP levels which are regularly seen in active cases of rheumatoid arthritis $^{21215}$ and Crohn's disease respectively. ${ }^{14}$ Although patients with uncomplicated SLE have been reported with high CRP values ${ }^{216}$ all the published results confirm that this is exceptional. ${ }^{13} 17$ Measurement of serum CRP is therefore a valuable aid in the diagnosis of intercurrent infection in febrile patients with SLE, ${ }^{13}$ and this may also be true in dermatomyositis.

We thank Mrs Christine Hutson for technical assistance. This work was supported in part by MRC programme grant G979/51 to M.B.P. R.F.D. was supported by the MRC of Canada. 


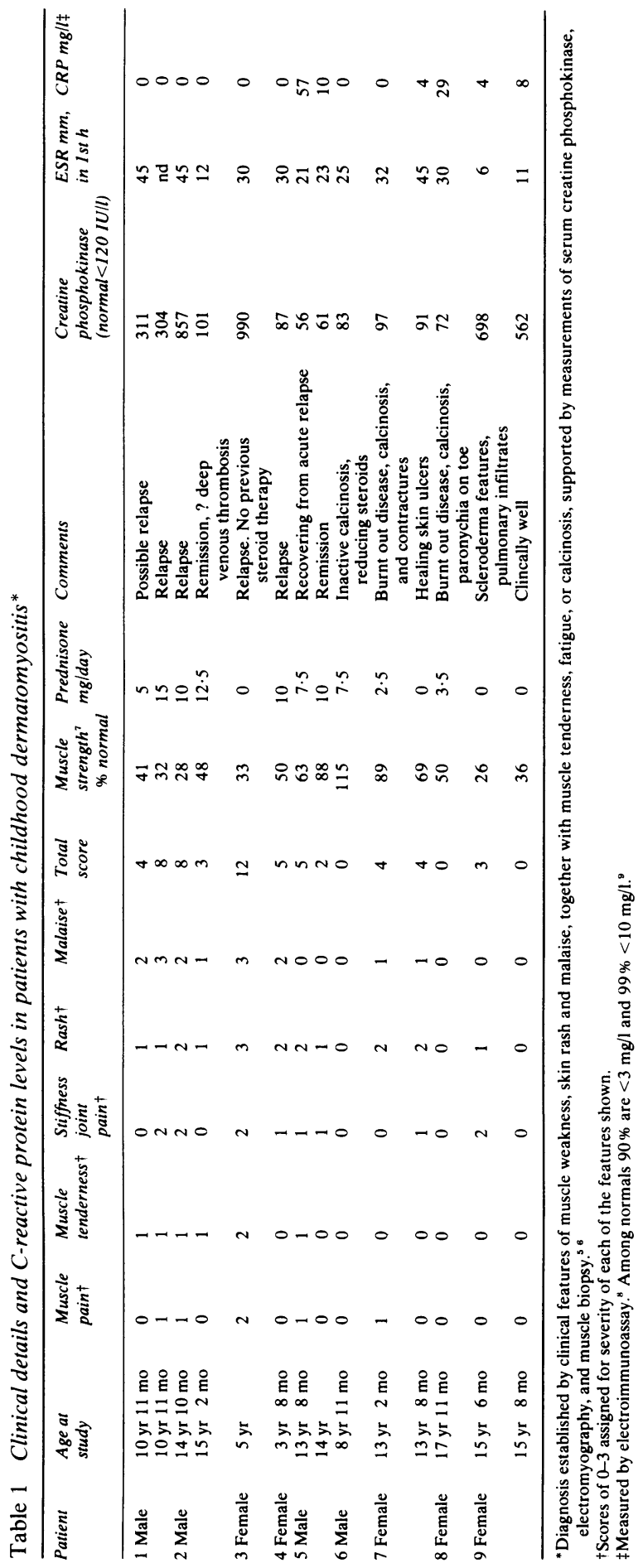




\section{References}

${ }^{1}$ Pepys M B. C-reactive protein fifty years on. Lancet 1981; i: 653-7.

${ }^{2}$ Pepys M B. C-reactive protein (CRP), serum amyloid P component (SAP) and serum amyloid A protein (SAA) in autoimmune disease. In: Holborow $\mathrm{E} \mathrm{J}$, ed. Clinics in Immunology and Allergy. Eastbourne: W B Saunders, 1981; 1: 77-101.

${ }^{3}$ Pepys M B. Aspects of the acute phase response. The C-reactive protein system. In: Lachmann P J, Peters D K, eds. Clinical Aspects of Immunology. Oxford: Blackwell Scientific Publications, in press.

4 Hill A G S. C-reactive protein in chronic rheumatic diseases. Lancet 1951; i: 807-11.

5 Dubowitz V. Muscle Disorders in Childhood. London, Philadelphia, Toronto: W B Saunders, 1978.

6 Dubowitz V, Brooke M H. Muscle Biopsy: A Modern Approach. London, Philadelphia, Toronto: W B Saunders, 1973: 319.

${ }^{7}$ Hosking G P, Bhat U S, Dubowitz V, Edwards R H T. Measurements of muscle strength and performance in children with normal and disease muscle. Arch Dis Child 1976; 51: 957-63.

${ }^{8}$ Pepys M B, Dash A C, Markham R E, Thomas H C, Williams B D, Petrie A. Comparative clinical study of protein SAP (amyloid P component) and C-reactive protein in serum. Clin Exp Immunol 1978; 32: 119-24.

9 Shine B, de Beer F C, Pepys M B. Solid phase radioimmunoassays for C-reactive protein. Clin Chim Acta 1981; in press.
${ }^{10}$ Honig S, Gorevic P, Weissmann G. C-reactive protein in systemic lupus erythematosus. Arthritis Rheum 1977; 20: 1065-70.

11 Becker G J, Waldburger M, Hughes G R V, Pepys M B. Value of serum C-reactive protein measurement in the investigation of fever in systemic lupus erythematosus. Ann Rheum Dis 1980; 39: $50-2$.

12 de Silva P A, Elkon K, Hughes G R V, Dyck R F, Pepys M B. $C$-reactive protein levels in systemic lupus erythematosus: a classification criterion? Arthritis Rheum 1980; 23: 770-1.

13 Pepys M B, Lanham J, de Beer F C. C-reactive protein in systemic lupus erythematosus. In: Hughes G R V, ed. Systemic Lupus Erythematosus. Clinics in the Rheumatic Diseases. Eastbourne: W B Saunders, 1981: in press.

${ }^{14}$ Pepys M B, Druguet M, Klass H J, Dash A C, Mirjah D D, Petrie A. Immunological studies in inflammatory bowel disease. In: Porter R, Knight J, eds. Immunology of the Gut, Ciba Foundation Symposium 46 (new series). Amsterdam: Elsevier/Excerpta Medica/North-Holland, 1977, 283-304.

15 Amos R S, Constable T J, Crockson R A, Crockson A P, McConkey $B$. Rheumatoid arthritis: relation of serum $C$-reactive protein and erythrocyte sedimentation rates to radiographic changes. $\mathrm{Br}$ Med J 1973; i: 195-7.

16 Zein N, Ganuza C, Kushner I. Significance of serum C-reactive protein elevation in patients with systemic lupus erythematosus. Arthritis Rheum 1979; 22: 7-12.

${ }^{17}$ Bravo M G, Alarcon-Segovia D. C-reactive protein in the differential diagnosis between infection and disease reactivation in SLE. J Rheumatol 1981; 8: 291-4. 